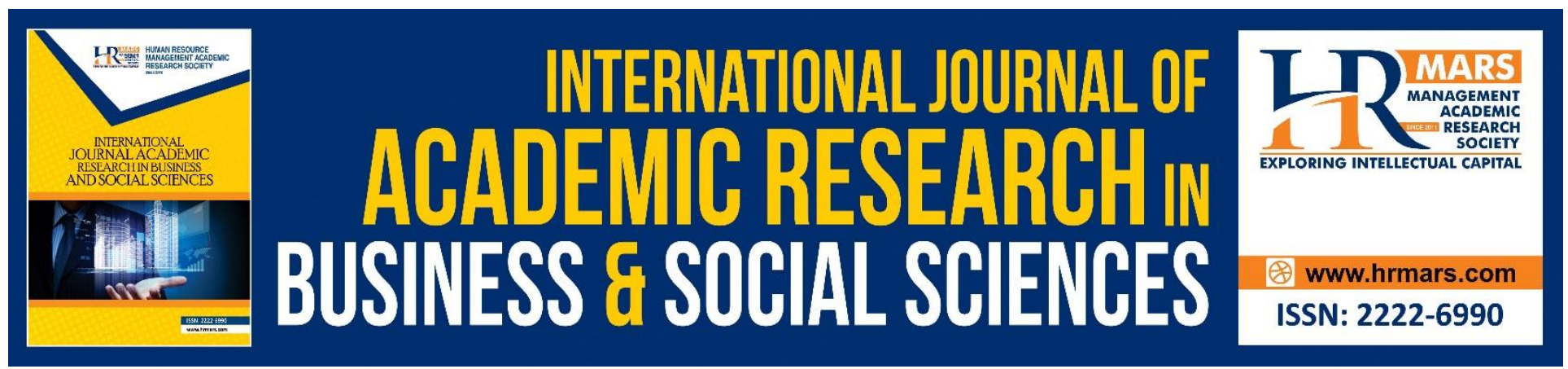

\title{
Muslim Tourists' Expectation towards Islamic Hospitality Services in Malaysia
}

\section{Noor Suhaila Yusof, Nurhazani Mohd Shariff, Hamimi Omar}

To Link this Article: http://dx.doi.org/10.6007/IJARBSS/v9-i6/5911

DOI: $10.6007 /$ IJARBSS/v9-i6/5911

Received: 19 April 2019, Revised: 08 May 2019, Accepted: 27 May 2019

Published Online: 21 June 2019

In-Text Citation: (Yusof, Shariff, \& Omar, 2019)

To Cite this Article: Yusof, N. S., Shariff, N. M., \& Omar, H. (2019). Muslim Tourists' Expectation towards Islamic Hospitality Services in Malaysia. International Journal of Academic Research Business and Social Sciences, 9(6), 110.

Copyright: (C) 2019 The Author(s)

Published by Human Resource Management Academic Research Society (www.hrmars.com)

This article is published under the Creative Commons Attribution (CC BY 4.0) license. Anyone may reproduce, distribute, translate and create derivative works of this article (for both commercial and non-commercial purposes), subject to full attribution to the original publication and authors. The full terms of this license may be seen at: $\underline{\text { http://creativecommons.org/licences/by/4.0/legalcode }}$

Vol. 9, No. 6, 2019, Pg. 1 - 10

Full Terms \& Conditions of access and use can be found at http://hrmars.com/index.php/pages/detail/publication-ethics 


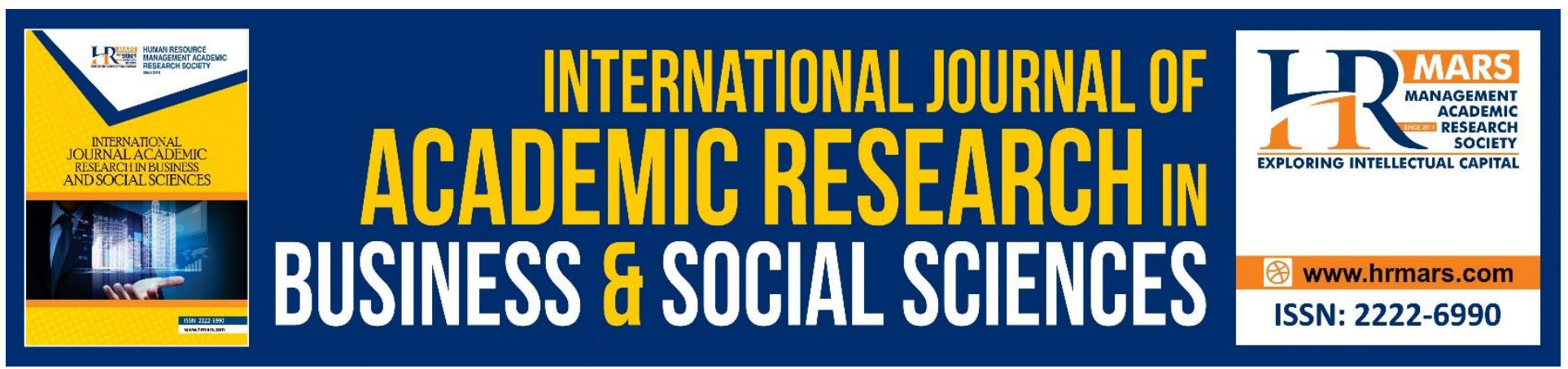

\title{
Muslim Tourists' Expectation towards Islamic Hospitality Services in Malaysia
}

\author{
Noor Suhaila Yusof \\ Nurhazani Mohd Shariff \\ Hamimi Omar \\ School of Tourism, Hospitality and Event Management, Universiti Utara Malaysia, 06010 Sintok, \\ Kedah Darul Aman, Malaysia \\ Email: nsuhaila@uum.edu.my, hazani@uum.edu.my, hamimi@uum.edu.my
}

\begin{abstract}
Previous studies found that the Muslim traveller population has been increasing and they bring a significant economic impact to the receiving country. Realising this, Malaysia has been stepping up their efforts in order to attract this group of tourist. However, Muslim groups choose the destination that they wish to visit based on several criteria, which were found to be related to their religious obligation. The availability of Muslim friendly attributes is vital because Muslim friendly attributes is one of the most important factor that influence Muslims' decision when they decide to travel abroad. Although previous studies have indicated the issues regarding Islamic hospitality services with destination selection, they did not emphasize on the importance of these in the context of Malaysia as a travel destination. The purpose of this paper is to highlight the findings that have been gathered from international Muslim tourists to Malaysia in term of how they prioritise the thirteen items under the Islamic hospitality services, which has been classified under accommodation and amenities as well as the availability of halal food. The findings are useful for the policy makers, tourism marketers and also the service providers to understand better about what the Muslim tourists want and need when they are making decision to choose which destination to visit.
\end{abstract}

Keywords: Muslim Tourist, Islamic Hospitality Services, Muslim Friendly Destination

\section{Introduction}

The term hospitality refers to the products and services provided to tourists as they travel from one place to another. Previous authors have defined the hospitality in various ways. Hospitality is defined as 'The provision of food and/or drink and/or accommodation away from home' by the Joint Hospitality Industry Congress (1996: 13). Likewise, Pfeifer (1983: 191) defined hospitality as 'Offering food, beverage and lodging, or, in other words, of offering the basic needs for the person away from home'. When it comes to defining the term Islamic hospitality services, it is about providing all these 
INTERNATIONAL JOURNAL OF ACADEMIC RESEARCH IN BUSINESS AND SOCIAL SCIENCES Vol. 9, No. 6, June, 2019, E-ISSN: 2222-6990 @ 2019 HRMARS

hospitality services according the Islamic teachings or the so-called Sharia law. According to Azreen Hamiza (2017), Islamic hospitality is about treating the guests in a way that everything is in accordance to the regulation of Islam, which has been clearly stated in the Quran and Hadith. Thomas (2008) explained Islamic hospitality as providing specific religious requirements of Muslim consumers. In addition, all the products that are regarded as Muslim friendly must be Halal and compliant with Sharia regulations (Zamani-Farahani \& Henderson, 2010). In addition, authors such as Rosenberg and Choufany (2009) and Henderson (2010) agreed that halal hospitality includes the so called Sharia compliant hotels that provides their guests with accommodation, food and other services that complies with the Sharia regulations.

\section{Literature Review}

\section{The Demand for Islamic Hospitality Services}

The growth of Muslim tourist population has driven a huge demand for Muslim friendly products and services (Crescentratings, 2018), which includes Islamic hospitality services (Azreen Hamiza, 2017). According to Jafari and Scott (2014), Muslim tourists choose a particular destination based on their perceptions, behaviour as well as emotions about the destination. The travel may be influenced by their main purpose of travel, which could be religious based (such as haj and umrah) or non-religious based (such as business, leisure, shopping etc.). However, even if the purpose of travel has no religious intention, these tourists must comply with the Islamic laws (Cohen, 2004). Therefore, destinations that can satisfy their specific needs may be appealing to them.

Based on a report by Tourism Malaysia (2016), some of the Muslim tourist came from rich countries and they were found to be some of the top spenders in Malaysia. For example, it has been reported that the per capita spending of tourists from Saudi Arabia in 2016 was RM10,185.70. Due to this fact, Malaysia was not the only country that is targeting this niche group of tourists. In fact, the nonMuslim countries such as Japan has also introduced Muslim friendly products and services as well as halal food premises across their country. They have earned 126 billion USD from the Muslim travel market (Halal Japan, 2017). This shows how significant this group is to the receiving country and Malaysia, as a Muslim country, should take this opportunity to attract more Muslim tourists to visit this country. However, this calls for an improvement to the hospitality services that can satisfy the specific needs of these people.

Islamic hospitality services can be defined as any type of services and facilities offered, to fulfil the Muslim tourists needs and that must be Halal and compliant with Sharia regulations. For example, Islamic hospitality services must consist of Halal dining options, easy to access to prayer locations, airport services and facilities, and accommodation options (Global Muslim Lifestyle Tourism Market, 2016). In addition, Zamani-Farahani and Henderson (2010) stated that Islamic hospitality services are referring to the characteristics of Islamic norms and values being practiced at the destination. In term of accommodation, Muslim friendly hotels, which are also known as Sharia compliance hotel (Sahida, Ab Rahman, Awang \& Che Man 2011). This type of hotels provides accomodation and services according to the Sharia (the Muslim law) (Shamim, 2009), which all Muslim are required to follow (Doi, 2006). In relation to that, Rosenberg and Choufany (2009) highlighted that Muslim friendly hotels should provide facilities such as gymnasium, swimming pools and spas separately for male and 
female Muslim guests. Therefore it is important to examine the level of expectations that the Muslim tourists have when they travel to Malaysia.

In addition, Taha and Center (2015) stated that majority of the Muslim tourists prefer Muslim friendly accommodation and destination that can offer halal food, with clean and hygienic environment. This is because Muslim consumers must be aware of the food they consume no matter where they are because of the religious requirement (Aiedah, 2012).This proves that the availability of halal food at a tourism destination is very important for the Muslim tourists. According to Meng, Tepanon and Uysal (2008), a destination that can fulfil the needs of tourist or preferred destination attributes will be more likely to be chosen. With regards to the Muslim tourists, Weidenfeld and Ron (2008) stated that various choices of halal foods was found to be one of the important attributes in order to create a Muslim friendly image of Malaysia.

\section{Methodology}

Due to the ease of understanding and completion of feedbacks from respondents, this study distributed a pre-tested questionnaire to the Muslim tourists. The questionnaire is divided into two sections. Section A of the questionnaire is meant to acquire the demographic information such as gender and age. Section B seeks to investigate about the Muslim tourists' expectation about the Islamic hospitality services as they travel abroad. The question in Section B consisted of 12 Islamic hospitality services adapted from previous studies conducted in various areas and scope (i.e. Al Hamarneh, 2008; Battour et. al., 2010; Battour et. al., 2014; Fatemeh \& Badaruddin, 2015; Global Muslim Travellers Index, 2018). Respondents will be asked to rate the list of Islamic hospitality services based on a given scale. The scale was developed on a five-point Likert scale ranging from 1 (Not at all Important) to 5 (Very Important). Only international Muslims tourists have been selected as respondents for this study. The data collections were done between October 2018 and January 2019, which ended with 462 usable feedbacks.

\section{Findings \\ Demographic}

Respondents for this study are the international Muslim tourists, who at that time were visiting Malaysia for various purposes. In term of gender differences, almost equal number of male and female tourists participated with $51.5 \%$ (238) male and $48.5 \%$ (224) female. In term of age, the biggest cluster of age group falls under the $20-30$ years old $(59.3 \%, n=274)$, which is followed by $22.9 \%$ (106) respondents who are aged between $31-40$ year old. The third group was the 41-50 years old which consist of $43(9.3 \%)$ respondents. This is followed by those who are below 19 years old $(5.8 \%$, $\mathrm{n}=27) ; 11(2.4 \%)$ respondents who are in the $51-60$ years old group, and only one person $(0.2 \%)$ is more than 61 years old. In term of region of origin, the biggest proportion of respondents for this study came from the Middle East with 44.8\% (207), followed by ASEAN, 32\% (148), South Asia, 5.6\% (26) and West Asia 5.0\% (23). In term of level of religiosity, 235 (50.9\%) respondents agreed that they are "religious", which is followed by a group of Muslims who claimed that they are "mildly religious" $(25.3 \%, n=117)$. Another group that claimed that they are "very religious" followed next with a total of $83(17.9 \%)$ respondents. Lastly, $27(5.8 \%)$ of the Muslim tourists admitted that they are "secular" Muslims. 
INTERNATIONAL JOURNAL OF ACADEMIC RESEARCH IN BUSINESS AND SOCIAL SCIENCES

Vol. 9, No. 6, June, 2019, E-ISSN: 2222-6990 (C) 2019 HRMARS

\section{Findings and Discussions}

This section discusses about the feedback from the Muslim tourists in Malaysia about their expectation of hospitality services when they visit this country. The results were analysed using a questionnaire which consists of questions where the tourists need identify their expectation level based on a five-point likert scale. Scale 1 for being "not at all important" to 5 being "very important". Each of the attributes will show whether they have been negatively assessed (below 3.00) or positively assessed (over 3.00). The assessments were divided into two attributes. First was about accommodations and amenities and second was regarding the availability of halal food, which has been represented by seven and five items respectively.

Figure 1 and 2 illustrates the mean scores of each item which were analyzed from the survey that the researcher gathered from international Muslim tourists in Malaysia. Results from the survey have been arranged to show which item have been rated as the highest mean score to the lowest. The higher the mean score indicates that these Muslim tourists put the higher importance about each of the attributes. Overall, the feedbacks for both attributes showed mean scores of more than 3.00, which indicate that they have positive expectation on all the listed attributes. The detailed response of each items are explained in the following section.

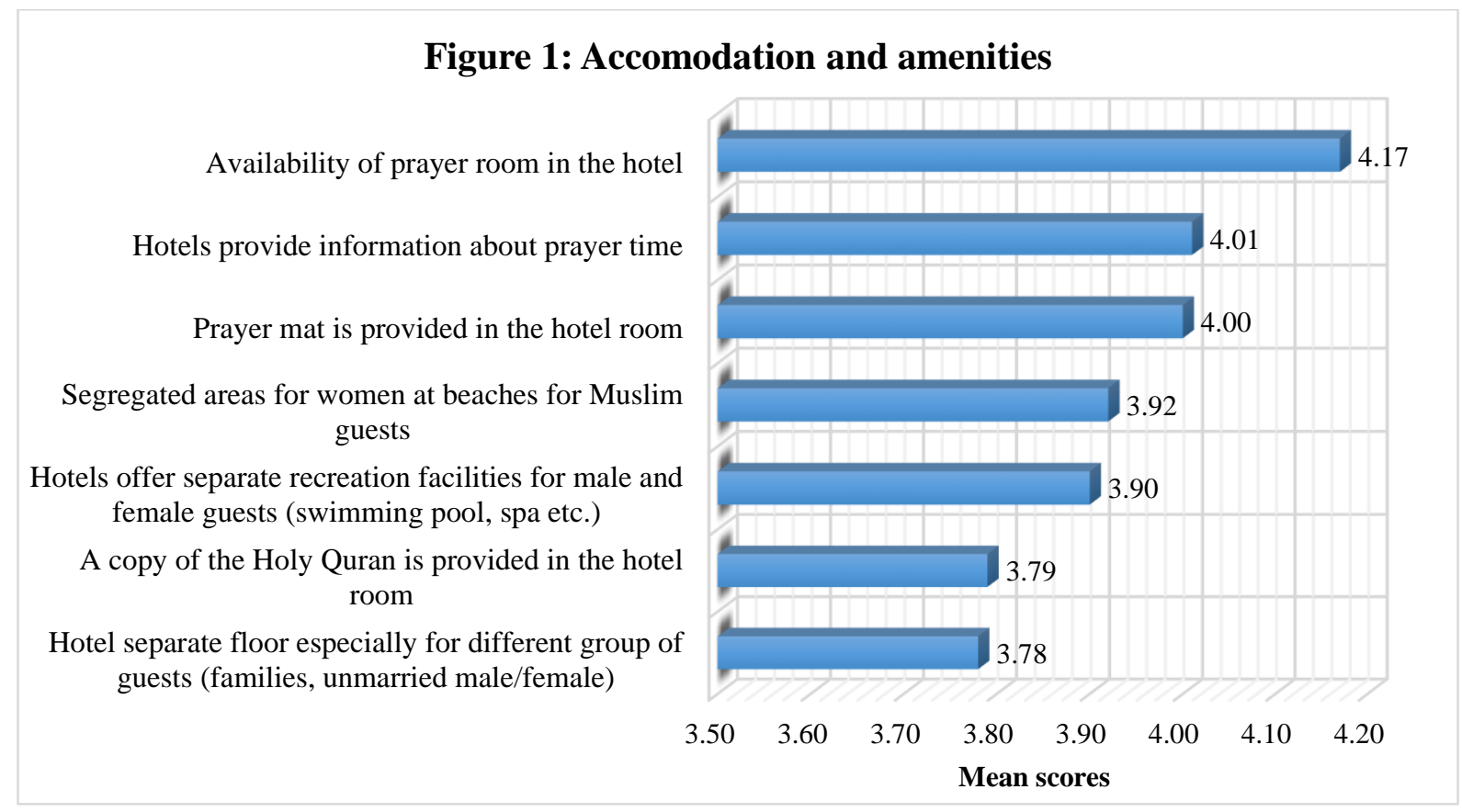

As displayed in Figure 1, in term of accommodations and amenities attribute, the Muslim tourists placed their highest expectations on the availability of prayer rooms in hotels, with the highest mean score of 4.17. This supports the findings by Musa, Ali and Moghavvemi (2016) who found that prayer rooms are very important for the Muslim tourists where they can perform their daily prayers. The results of this study is also in line with the findings from Al Hamarneh (2008) and Battour, et al. (2010) where they also found that the Muslim tourists' satisfaction will depend on among others, the 
availability of prayer rooms on site. Other than that, they also put a high priority about the availability of prayer times (mean score of 4.01) and also the availability of prayer mat in the hotel room ( $\mathrm{M}=$ 4.00). A good explanation for this is that since they are traveling abroad and the five times prayer is compulsory, a display of the prayer time would be very helpful for them to fulfil their religious obligation. Also when we refer to the statistics, the top three priority that has been rated by the Muslim tourists were about performing the daily prayers. This shows how important the daily prayers are for the Muslims and therefore any hospitality provider that want to attract this group should consider this element as their top priority.

The next important factor that the Muslim tourists consider when making decision is about the recreational facilities. As what has been stated in the Sharia law, unmarried men and women should be separated because Muslims have limitation especially when socializing themselves in the community, thus the segregation of gender is important (Kessler, 2015). Taha and Center (2015) stated that one of the most important factor that the Muslim tourist consider when choosing a hotel is that the hotel provide separate or different time schedule for male and female guests to use the recreation facilities such as gymnasium and the swimming pool. In addition, Battour (2010) and Battour et al. (2014) also suggested that hotels should provide separate recreational facilities for men and women. In this particular study, the researchers found that the Muslim tourists looked at hotels that "Segregated areas for women at beaches for Muslim guests" and "Hotels offers separate recreation facilities for male and female guests (swimming pool, spa, etc.)" as very important and the mean score for the two factors were 3.92 and 3.90 respectively. This shows that the current study agreed with the previous studies where the Muslim tourists put high expectation on the separation of gender in recreational facilities.

The least important factor that they considered was the separation of floors between groups of families (families, unmarried male / female). Nevertheless, even though this factor scored the least among six other factors, it is still considered as important by this group of tourists (mean score of 3.78). This is because according to Mansouri (2014), the separation of floor between these groups may encourage guests to stay even longer at the hotel. Based on the seven factors aforementioned, it can be summarised that providing hospitality and amenities according to the Muslim needs will have an impact to the Muslim tourists' choice because they put high importance on all of these aspects. Furthermore, Weidenfeld and Ron (2008) highlighted the importance of providing facilities based on religious needs because these tourists will choose a destination that have all the facilities that enable them to obey or perform their religious needs. 
INTERNATIONAL JOURNAL OF ACADEMIC RESEARCH IN BUSINESS AND SOCIAL SCIENCES Vol. 9, No. 6, June, 2019, E-ISSN: 2222-6990 (C) 2019 HRMARS

Figure 2: Availability of Halal food

Easy to get halal food at tourism sites and public places (airports, shopping mall, hotels, etc.)

Easy to find places that provides halal food and beverages such as restaurant, cafe, food stalls

Food premises display halal logo or certificates at their premises

Easy to differentiate between halal and non-halal food outlets in Malaysia

Non-halal food or beverages are not served in the Hotel room's mini bar

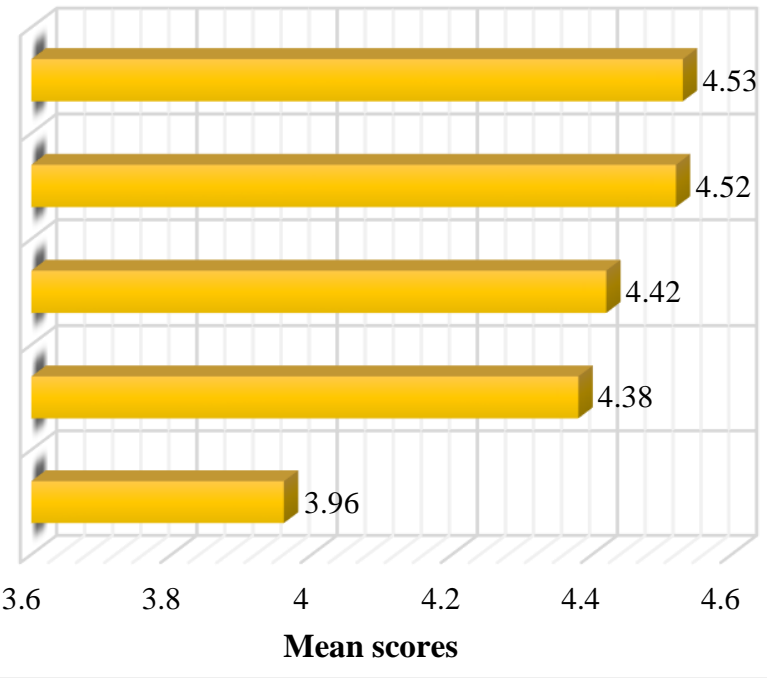

In term of availability of halal food, the mean scores of availability of halal food factor has the highest summated mean score of 4.36, showing that respondents agreed that it is almost "very important" for a destination to offers availability and varieties of halal food especially for Muslim tourists at the destination. More specifically, respondents agreed that it is important for them to "easily get halal food at tourism sites and public places (airports, shopping mall, hotels, etc.)" (with the highest mean score of 4.53), followed by "easy to find places that provides halal food and beverages such as restaurant, café and food stalls" (mean score of 4.52) (Figure 2). These findings confirmed that the availability of halal food is very important for these Muslim tourists, which also have been discovered in previous studies (such as Battour et al. 2010; Aiedah, 2012; Taha and Center 2015; and Weidenfeld \& Ron, 2008). In addition, Battour et al. (2013) claimed that halal food was found to be the second most important Muslim friendly attributes after worship facilities. Also, Weidenfeld and Ron (2008) pointed out that the availability of halal cuisine as one of the important factor in creating a Muslim friendly image of a destination.

Other halal aspects that has been highly regarded by the Muslim Tourists are about the ability to recognise the halal status of food or food premise. They have high expectation towards restaurants that declare whether they are halal or not by displaying either the halal logo or certificates at their premise (mean score of 4.42). From this, they also expect to easily tell whether the food outlet is halal or not (mean score of 4.38). In the providers' point of view, halal certification signifies the status of the restaurant that not only the food served are halal but also includes the entire process (Sharifah Zannierah, Hall \& Ballantine, 2012). As for the Muslim tourists, the halal status of the food outlets will help them to choose more comfortably when it comes to food selection. As suggested by Dugan (1994), those who can provide food according to Muslims' needs will attract more customers. Also, without the Islamic aspects such as availability of halal food, Muslim tourists may avoid from choosing that particular destination (Battour, Ismail, \& Battor, 2011). 
INTERNATIONAL JOURNAL OF ACADEMIC RESEARCH IN BUSINESS AND SOCIAL SCIENCES Vol. 9, No. 6, June, 2019, E-ISSN: 2222-6990 @ 2019 HRMARS

\section{Conclusion}

This paper has presented about the Muslim tourists' expectation about the Islamic hospitality services when they travel abroad. Muslim tourists are becoming more concerned about Muslim friendly products and services especially when they are travelling away from their own country. With regards to the Islamic rules as discussed above, it is important for a destination to develop and offer products and services especially for the Muslim travel market. It is important to understand the importance of Islamic hospitality services from the perspective of Muslim, because a study of the particular attributes of a destination would provide insights or/and clues which could help destination marketers in promoting and developing the destinations (Uysal, Li \& Sirakaya, 2008). This information can help the government to decide which of the attributes to be focused in helping Malaysia to stay above competitors in attracting the Muslim market. Previous studies in understanding Muslim tourists regarding the Islamic hospitality service is still lacking. Hence, the current study focussed on the importance of Islamic hospitality services from the expectation of Muslim travellers to Malaysia. The respondents for this study were the international Muslim tourists that currently visiting Malaysia for various purposes. This paper covered two major aspects of Islamic hospitality services namely, lodging and amenities and availability of halal food. Results showed that the Muslims placed high expectation on all aspects that were listed under both attributes under the Islamic hospitality services. In term of lodging and amenities, the Muslim tourists regarded all three items regarding performing the five time prayers as the most important. The availability of prayer room in hotel, availability of prayer time and prayer mats in the hotel rooms were found to be the top priority for them when it comes to choosing accommodation. The next important factors that were highly anticipated by these tourists were about the separation between unmarried male and female guests and the availability of Quran in the hotel room. The findings have confirmed with previous studies here these Muslim tourists have high expectation of their ability to perform their religious obligation and that it will influence their decision when choosing a destination.

In term of the availability of halal food, the Muslim tourists put high expectations on their ability to identify the halal status of the food and food premises that are made available for them. The highest expectations were placed on the ease of getting halal food wherever they go or visit. Other than that, they also expect to see the halal logo or certificates, which can help them to determine whether the food is halal or not. This is also an important finding to show that the Muslim tourists follow the Islamic rules wherever they are and those who can provide this will gain the competitive advantage against their competitors. As been stated in previous study, because of the purchasing power of these tourists, even non-Muslim countries are pursuing this niche group. Therefore, it is important for Malaysia as a Muslim country to strengthen Islamic hospitality services to draw this group's interest to visit the country.

Finally, it is important to emphasize here that even though not all Muslim follow strictly all the Islamic rules as being stated in Quran and Hadith, it is huge advantage for the service providers or even a country that can provide Islamic hospitality services that could satisfy the needs of the Muslim tourists. The findings presented in this paper could help the marketers and service providers to better understand the needs if the Muslim tourists in terms of what they expect from the hospitality services. The service provider or the destination could enhance their likelihood of being chosen by these Muslims by identifying and enhancing all these important attributes in their marketing strategy. 
Therefore based on the findings of this part of the study, the author could suggest to the tourism governing bodies, including the private sectors to continue to focus on promoting and advertising about the availability of halal food in the country; and also diverse range of a Muslim friendly accommodations and amenities for tourists.

\section{References}

Aiedah, A. K. (2012). Young consumers' attitude towards halal food outlets and JAKIM's halal certification in Malaysia. Procedia - Social and Behavioral Sciences. 121, 26-34.

Al-Hamarneh, A. (2008). New Tourism Trends in the Arab World. Islamic Tourism, 16.

Hamiza, A. A. (2017). Conceptualising Islamic Hospitality Management. (PhD Thesis), Universiti Sains Malaysia.

Battour, M., Ismail, M. N., \& Battor, M. (2010). Islamic attributes of a destination: Construct development and measurement validation and their impact on tourist satisfaction. International Journal of Tourism Research, 16(6), 556-564.

Battour, M, Ismail, M. N., \& Battor, M. (2011). The Impact of destination attributes on Muslim tourist's choice. International Journal of Tourism Research, 13(6), 527-540.

Battour, M., Battor, M., \& Bhatti M.A. (2013). Islamic attributes of destination: Construct development and measurement validation, and their impact on tourist satisfaction. International Journal of Tourism Research.

Battour, M., \& Ismail M. N. (2014). The roles of Islamic attributes in Islamic Tourism. SHS Web of Conferences, 12.

Cohen, S. (2004). Social relationship and health. American Psychologist.

Crescentrating (2018). Global Muslim Travel Index 2018. Retrieved from: https://www.crescentrating.com/reports/mastercard-crescentrating-global-muslim-travelindex-gmti-2018.html

Doi, A. R. I. (2006). Shariah: The Islamic Law. Islamic Book Trust Publishers Ltd., 1-500.

Dugan, B. (1994). Religion and Food Service. Cornell Hotel and Restaurant Administration Quarterly. 35, 80-85.

Fatemeh, S. \& Badaruddin, M. (2015). Malaysia's branding as an Islamic hub: An Assessment. GEOGRAFIA ONLINE Malaysia Journal of Society and Space, 11 (1), 97-106.

Global Muslim Lifestyle Tourism Market (2016). Global Muslim Lifestyle Tourism Market2015: Landscape \& Consumer Needs Study. Retrieved from: http://www.dinarstandard.com/travelstudy/

Global Muslim Travellers Index (2018). Global Muslim Travel Index 2018. Retrieved from: https://www.crescentrating.com/reports/mastercard-crescentrating-global-muslim-travelindex-gmti-2018.html

Halal Japan (2017). Muslim, Halal friendly Japan Portal. Retrieved from: www.halaljapan.com Henderson, J.C. (2010). Sharia-compliant hotels. Tourism and Hospitality Research, 10(3), $246-254$. Jafari, J., \& Scott, N. (2014). Muslim world and its tourisms. Annals of Tourism Research, 44, 1-9. Kessler, K. (2015). Conceptualizing Mosque Tourism: A central feature of Islamic and Religious Tourism. International Journal of Religious Tourism and Pilgrimage, 3(2), 13-19. 
INTERNATIONAL JOURNAL OF ACADEMIC RESEARCH IN BUSINESS AND SOCIAL SCIENCES

Vol. 9, No. 6, June, 2019, E-ISSN: 2222-6990 @ 2019 HRMARS

Mansouri, S. (2014). Role of Halal Tourism Ideology in Destination Competitiveness: A Study on Selected Hotels in Bangkok, Thailand. In International conference on Law, Education and Tourism studies.

Meng, F., Tepanon, Y. \& Uysal, M. (2008). Measuring Tourist Satisfaction by Attribute and Motivation: The Case of a Nature-Based Resort. Journal of Vacation Marketing, 14, 41-56. DOI: 10.1177/1356766707084218.

Musa, G., Ali, S. M., \& Moghavvemi, S. (2016). Understanding Islamic (halal) tourism through Leiper's tourism system. 1-25.

Pfeifer, Y. (1983). Small business management. In: Cassee, E.H., Reuland, R., (eds). The Management of Hospitality. Oxford: Pergamon. 189-202.

Rosenberg, P. \& Choufany, H. (2009). Spiritual Lodging - The Sharia-Compliant Hotel Concept. Retrieved from: http://www.hospitalitynet.org/news/4041066.html

Zannierah, S. M., Hall, C. M. \& Ballantine, P. W. (2012). Restaurant Manager and Halal Certification in Malaysia, Journal of Foodservice Business Research, 15 (2), 195-214.

DOI: $10.1080 / 15378020.2012 .677654$

Shamim, Y. (2009). The real sense of Shariah hospitality concept. In The World Halal Forum, Kuala Lumpur, Malaysia.

Taha, R. M. \& Center, U. C. S. (2015). Maqasid Al Shariah in the Governance and Management Strategy of Islamic. Tourism Businesses.

The Joint Hospitality Industry Congress (1996). Hospitality into the $21^{\text {st }}$ century. Henley Center: Henley.

Tourism Malaysia (2016). Malaysia Tourism key performance indicator 2016. Retrieved from: http:// www.tourism.gov.my/media/view/malaysia-s-2016-key-performance

Thomas, K. (2008). Islamic hospitality sector emerges. MEED: Middle East Economic Digest, 52(18), 55-57.

Uysal, M., Li, X. \& Sirakaya, E. (2008). Push-pull dynamics in travel decision. Handbook of hospitality.

Sahida, W., Ab Rahman, S., Awang, K., \& Che Man, Y. (2011). The Implementation of Shariah Compliance Concept Hotel: De Palma Hotel Ampang, Malaysia. In $2^{\text {nd }}$ International Conference on Humanities, Historical, and Social Sciences (IPEDR), IACSIT Press, Singapore.

Weidenfeld, A., \& Ron, A. (2008). Religious needs in the tourism industry. Anatolia: International Journal of Tourism and Hospitality Research, 19(2), 18-22.

Zamani-Farahani, H. \& Henderson, J. C. (2010). Islamic tourism and managing tourism development in Islamic societies: the cases of Iran and Saudi Arabia. International Journal of Tourism Research, 12(1), 79-89. 